\title{
BMPR-1B, BMP-15 and GDF-9 genes structure and their relationship with litter size in six sheep breeds reared in Egypt
}

\author{
Ahmed. A. Saleh ${ }^{1,2^{*}}$, M. H. Hammoud ${ }^{2}$, Nasraa A. Dabour ${ }^{3}$, E. E. Hafez ${ }^{4}$ and Mahmoud A. Sharaby ${ }^{2}$
}

\begin{abstract}
Objective: The aim of this work was to investigate three different mutations; Fec-B, Fec $X^{G}$, Fec- $G^{H}$ at three candidate genes; Bone morphogenetic protein receptor IB, Bone morphogenetic protein 15 and Growth Differentiation Factor 9 , respectively, in six sheep breeds reared in Egypt namely; Rahmani, Barki, Rahmani X Barki cross, Awassi, Awassi X Suffolk cross, and Ossimi and their association with litter size.

Results: Genomic DNA of 132 sheep was investigated for the Fec-B, FecX ${ }^{G}$, and Fec-GH mutations by Restriction Fragment Length Polymorphism, Single-Stranded Conformation Polymorphism and DNA sequencing. The results revealed that all breeds did not carry Fec-B mutation. On the other side, the mutations of Fec ${ }^{G}$, and $F e c-G^{H}$ were detected in Rahmani, and Rahmani X Barki cross which is associated with the high twinning rate/litter size of Rahmani (1.28) and Rahmani X Barki cross (1.22). While, the average litter size for other breeds had almost a constant values rate over six parities, ranging between 1.00 and 1.04 .
\end{abstract}

Keywords: Fec-B, BMP-15, GDF9, RFLP, SSCP, DNA sequencing

\section{Introduction}

The productive and reproductive traits are influenced by a large number of minor genes scattered across the genome [1]. Selection for these genes requires special tools, pedigree assisted selection and progeny testing have been used widely to improve many of these traits [2]. Fertility, though being one of these traits, it possesses lowly heritable nature due to strong environmental influences. Additionally, fertility is controlled by the Bone morphogenetic protein receptor IB (BMPR-IB), bone morphogenetic protein 15 (BMP15) and Growth Differentiation Factor 9 (GDF9) genes. These major genes were found to participate in determining sheep fertility

\footnotetext{
*Correspondence: Elemlak1339@Gmail.Com

${ }^{1}$ College of Animal Science and Technology, Southwest University, Chongqing Key Laboratory of Forage \& Herbivore, Chongqing Engineering Research Center for Herbivores Resource Protection and Utilization, Beibei 400716, Chongqing, People's Republic of China Full list of author information is available at the end of the article
}

behaviour [2-8]. Presence of mutations in these genes increase ovulation and lambing rates dramatically with ewes producing 2, 3, or even more lambs per parturition [4], enhance reproductive endocrinology [9], and ovarian activity and product of litter size (LS), body mass and other organs development [10-13]. Several previous studies discussed the relationship of Fec-B, Fec- $\mathrm{G}^{\mathrm{H}}$, and $\mathrm{Fec} \mathrm{X}^{\mathrm{G}}$ mutations in the above-mentioned genes with major effects on LS and ovulation rate in sheep $[2,6,7$, $14,15]$.

The objectives of this work were to examine the presence of BMPR-1B (Fec-B), BMP-15 (Fec- $\mathrm{G}^{\mathrm{H}}$ ) and GDF9 $\left(\mathrm{Fec} \mathrm{X}^{\mathrm{G}}\right)$ mutations and their association with LS in six sheep breeds reared in Egypt using forced PCR-Restriction Fragment Length Polymorphism (PCR-RFLP), Single-Strand Conformational Polymorphism (SSCP) and DNA sequencing.

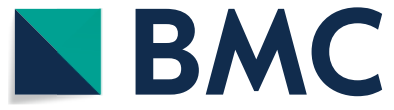

(c) The Author(s) 2020. This article is licensed under a Creative Commons Attribution 4.0 International License, which permits use, sharing, adaptation, distribution and reproduction in any medium or format, as long as you give appropriate credit to the original author(s) and the source, provide a link to the Creative Commons licence, and indicate if changes were made. The images or other third party material in this article are included in the article's Creative Commons licence, unless indicated otherwise in a credit line to the material. If material is not included in the article's Creative Commons licence and your intended use is not permitted by statutory regulation or exceeds the permitted use, you will need to obtain permission directly from the copyright holder. To view a copy of this licence, visit http://creativeco mmons.org/licenses/by/4.0/. The Creative Commons Public Domain Dedication waiver (http://creativecommons.org/publicdomain/ zero/1.0/) applies to the data made available in this article, unless otherwise stated in a credit line to the data. 


\section{Main text}

\section{Materials and methods}

Animals

Samples from six sheep breeds viz; Rahmani $(n=20$ ewes), Barki ( $n=20$ ewes), Awassi ( $n=10$ rams and ewes), Awassi X Suffolk ( $\mathrm{n}=8 \mathrm{rams}$ and ewes), Ossimi $(\mathrm{n}=5$ rams and ewes) and Rahmani $\mathrm{X}$ Barki cross ( $n=69$ rams and ewes) were obtained from three different geographical regions at the northern region of Egypt, namely; Alexandria University 'experimental station' (GPS: 31.206208, 29.919704)-Matrouh governorate (GPS: 31.336924, 27.205762) and Sakha (GPS: $31.087032,30.948859)$. The data records for LS have been investigated for each breed for six parities.

\section{DNA isolation and amplification}

Total genomic DNA was extracted from sheep blood samples with (QIAGEN kit, Germany). The DNAs were separated by electrophoresis on $0.8-1 \%$ agarose in $0.5 \times$ TBE buffer [16] which contained around $0.5 \mu \mathrm{g} / \mathrm{ml}$ ethidium bromide. The electrophoresis run was performed utilizing apparatus with power supply and visualized by ultra-violet transilluminator and Gel documentation system (Alpha-chem. Imager, USA). The specificities of the PCR primers targeting BMPR$1 \mathrm{~B}, \mathrm{BMP}-15$ and GDF-9 genes were previously tested by Wilson et al. [17], and Hanrahan et al. [18] (Additional file 2: Table S1). The amplifications were performed using (iQ SYBR G-S.mix, USA), 10 p.mol of each primer and $80 \mathrm{ng}$ of genomic DNA processed under the amplification conditions shown in (Additional file 2: Table S2). The amplification was carried out using a Thermo-cycler Gene Amp 6700 (Bio-system, USA).

\section{Restriction fragment length polymorphism (RFLP)}

The RFLP technique was used to detect the differences between sheep breeds, utilizing the PCR products of target genes. The PCR products of BMPR-1B gene were digested with AvaII (Jena Bioscience, Germany) and of GDF-9 with ASP-I and Hinf-I (Bio-search Technologies, USA) separately. The reaction volume was $25 \mu \mathrm{l}$, consisting of $10 \mu \mathrm{l}$ PCR product, $2 \mu \mathrm{l} 10 \times$ digestion buffer, $12 \mu \mathrm{l} \mathrm{H}_{2} \mathrm{O}, 5$ units restriction enzyme (5 unit/1 $\left.\mu \mathrm{l}\right)$. All reactions were incubated at $37{ }^{\circ} \mathrm{C}$ for $14-16 \mathrm{~h}$. $20 \mu \mathrm{l}$ of each reaction were separated by electrophoresis on $3-4 \%$ agarose gel. Similarities and differences between breeds were detected by inspecting RFLP patterns.

\section{Single-strand conformational polymorphism (SSCP)}

The SSCP analysis was employed according to Bastos et al. [19] to detect the possible mutations in BMP-15 gene. Aliquots of $7-10 \mu \mathrm{l}$ PCR products were mixed with 2-3 $\mu$ l of SSCP dye (95\% formamide, $0.025 \%$ bromophenol blue, $0.05 \%$ xylene-cyanole and $0.5 \mathrm{M}$ $\mathrm{pH}$ 8.0 EDTA, Mixture by vortexing and then storing at $-20{ }^{\circ} \mathrm{C}$ ), incubated at $95{ }^{\circ} \mathrm{C}$ for $5 \mathrm{~min}$ and then chilled on ice. Denatured DNA was loaded on 10\% PAGE gel $(90 \mathrm{~mm} \times 75 \mathrm{~mm} \times 0.75 \mathrm{~mm})$. Electrophoresis was performed on $0.5 \times$ TBE buffer at room temperature using the constant voltage of 70 to $90 \mathrm{v}$ for $5-6 \mathrm{~h}$.

\section{Nucleotide sequence analysis}

The sequence analysis was carried out for GDF-9 gene by DNA Sequencer (ABI Prism 3100 apparatus, USA). Database similarity searches were performed with (NCBI) (http://www.ncbi.nlm.nih.gov). The resulted sequences were analyzed using Blast 2.0, MEGA 5.05, to detect Single-Nucleotide Polymorphism (SNPs) among different samples. The sequences of GDF-9 gene for studied animals were deposited in GenBank (Accession Numbers: KT357481.1, КТ357482.1, КТ357484.1, КТ357483.1, KT357485.1, and KT357486.1) for Rahmani, Barki, Rahmani X Barki cross, Awassi, Awassi X Suffolk cross, and Ossimi, respectively. Analysis of translated amino acid of GDF-9 gene sequences of tested sheep breeds were generated using ExPASy program.

\section{Statistical analysis}

Data records of LS were tested for normality with the Shapiro-Wilk test from the UNIVARIATE procedure (SAS, 2004), and results indicated that all data were distributed normally [Shapiro-Wilk test $(W) \geq 0.90$ ]. Also, the GLM procedure of SAS was used to determine the effects of breed on ewes' prolificacy (or LS of ewes) according to the following model:

$$
Y_{i j}=\mu+B_{i}+e_{i j}
$$

Where: $Y_{\mathrm{ij}}=$ the ewes` prolificacy, $\mu=$ the overall mean, $B_{i}=$ the fixed effect of ith breed, and $e_{i j}=$ the residual error. Significant differences among means within each LS were tested using least significant difference $\left(\mathrm{LSD}_{0.05}\right)$.

\section{Results and discussion}

\section{Amplification, manipulation, and digestion}

This research note concerns mainly the differentiation between six sheep breeds for Fec-B, Fec- $\mathrm{G}^{\mathrm{H}}$ and $\mathrm{FecX}^{\mathrm{G}}$ mutations. It also spotlights the association between polymorphism of these mutations and their relationship with LS. PCR amplification for the tested sheep breeds produced an amplified $190 \mathrm{bp}$ fragment for BMPR-1B (Additional file 1: Figure S1a), $141 \mathrm{bp}$ fragment for BMP15 (Additional file 1: Figure S1b), and 462 bp fragment for GDF-9 (Additional file 1: Figure S1c). 


\section{BMPR-1B gene}

The PCR products of BMPR-1B gene obtained for tested animals after digestion with AvaII (Fig.S2a) revealed only one pattern for one DNA fragment sized $190 \mathrm{bp}$ and indicated the absence of a restriction site of AvaII. These results were in agreement with those found by Abulyazid et al. [20] on a total of 22 crossbred Egyptian sheep (11 twins producing a female, 7 single lambs producing a female, and 4 male). Also, was in agreement with the results of EL-Hanafy and El-Saadani [21]. who concluded an absence of the gene in five Egyptian sheep breeds. On the other hand, Guan et al. [22] found that; 7 out of 9 sheep breeds, namely, Suffolk, Charolais, $\mathrm{Hu}$, Chinese Merino prolific meat strain, Dorset, Romney Hills, Merino and crossbreed of Suffolk $\times$ Chinese Merino as well as Dorset $\times$ Chinese Merino were of wild-type $(++)$ with $190 \mathrm{bp}$ for the restriction pattern of Fec-B gene. They observed a positive relationship between Fec-B mutation and LS in Chinese Merino prolific meat strain. The BB homozygous mutant genotype sized around $2.84 \pm 0.74$ LS $(\mathrm{P}>0.05)$ which was greater $(\mathrm{P}<0.01)$ than that of ewes with ++ genotype $(1.23 \pm 0.68)$ LS. Also, the ewes with BB genotype produced 0.5 LS lambs more than those with B + genotype, though this difference was not significant.

\section{GDF-9 gene}

Digestion of PCR fragments of GDF-9 gene which was performed using two different restriction enzymes, $A S P-I$ and Hinf-I separately produced different PCR profiles. The ASP-I profile produced two fragments of 280 and 182 bp for all tested samples (Additional file 1: Fig. $\mathrm{S}_{2} \mathrm{~b}_{1}$ ) and the Hinf-I pattern gene produced 300, 110 and 52 bp bands for all tested breeds and crosses, (Additional file 1: Fig. $\mathrm{S}_{2} \mathrm{~b}_{2}$ ). The two digestion profiles indicated the presence of one genotype for all tested breeds. Therefore, to identify the genotypic diversity of GDF-9 $\left(\right.$ Fec- $\left.\mathrm{G}^{\mathrm{H}}\right)$ gene among the studied animals the complete sequences of all amplified fragments of this gene were performed for mutation detection.

\section{Nucleotide sequence and amino acid sequence comparisons for GDF-9 gene}

Nucleotide sequencing of the amplified fragment of GDF-9 gene of Rahmani, Barki, Rahmani X Barki cross, Awassi, Awassi X Suffolk cross, and Ossimi, respectively were performed and submitted to the NCBI GenBank (Accession Numbers: KT357481.1, KT357482.1, KT357484.1, КТ357483.1, КТ357485.1, and KT357486.1) (Additional file 1: Fig. S3). The nucleotide sequence analysis indicated that the percent distances of GDF-9 gene fragment of sheep breeds shown in (Additional file 2: Table S3), (Fig. 1) were generated by using MEGA 5.05 .

The sequence of the amplified GDF-9 gene fragments of tested sheep breeds as generated by ExPASy program and the comparison of amino acids obtained by MEGA 5.05 are in (Fig. 2). The amino acid sequence of Rahmani breed was different from that of other breeds by four amino acids. The different amino acids were (Lysine, Valine, Glutamic and Asparagin) in Rahmani instead of (Arginine, Glycine, Glycine, and Lysine) in other breeds, while in Rahmani X Barki cross the amino acid sequence was different from that of other breeds by three amino acids, the different amino acids were (Asparagine, Phenylalanine, and Serine), instead of (Lysine, Leucine, and Threonine). Otherwise, Barki breed amino acid sequence was different from that of other breeds in one amino acid, only that was (Phenylalanine) instead of (Isoleucine). The changing amino for all breeds is shown in (Additional file 2: Table S4). Hence, there was approximately (97.01\%) similarity in the amino acid sequence between tested animals.

On another level, Noshahr and Rafat [23]. studied the RFLP performed to detect the genetic diversity of GDF-9 $\left(\right.$ Fec- $\mathrm{G}^{\mathrm{H}}$ ) in Moghani sheep population and identified three different patterns. The first pattern yielded three DNA fragment-sized 52, 156 and 254 bp and was classified as $(\mathrm{FecG}+)$. The second pattern yielded two DNA fragments of 52 and $410 \mathrm{bp}$ and was classified as (FecG-). While the third pattern produced four DNA fragments of $52,156,254$ and $410 \mathrm{bp}$, the carriers of this pattern were classified as heterozygous for the mutation GDF-9 (Fec$\left.\mathrm{G}^{\mathrm{H}}\right)$ gene.

Therefore, the GDF9 gene can be considered as a possible candidate for increased LS in sheep [24]. In the present study, genetic variation were found within the GDF9 gene based on nucleotide sequence for Rahmani and its cross with Barki.

\section{BMP-15 gene \\ Genotyping of BMP-15 gene by SSCP technique}

Images of PCR products of SSCP technique performed to identify polymorphism and detect the alleles within BMP-15 gene, genotypes are in (Additional file 2: Table S5). The SSCP results for BMP-15 PCR product of separate breeds showed homozygous genotype (GG) of BMP-15 gene for Rahmani while, Rahmani X Barki cross had the three different genotypes (GG, G+, and $++)$, on the other side, there is only homozygous genotype $(++)$ for Barki, Awassi, Awassi X Suffolk cross, and Ossimi. Similar heterozygous genotype for BMP-15 was detected in small tailed Han sheep when two genotypes, $++(111 \mathrm{bp} / 111 \mathrm{bp})$ and $\mathrm{G}+(141 \mathrm{bp} / 111 \mathrm{bp})$ were identified by SSCP $[6,7]$. Detection of mutations for BMP-15 gene of Rahmani and its cross with Barki 


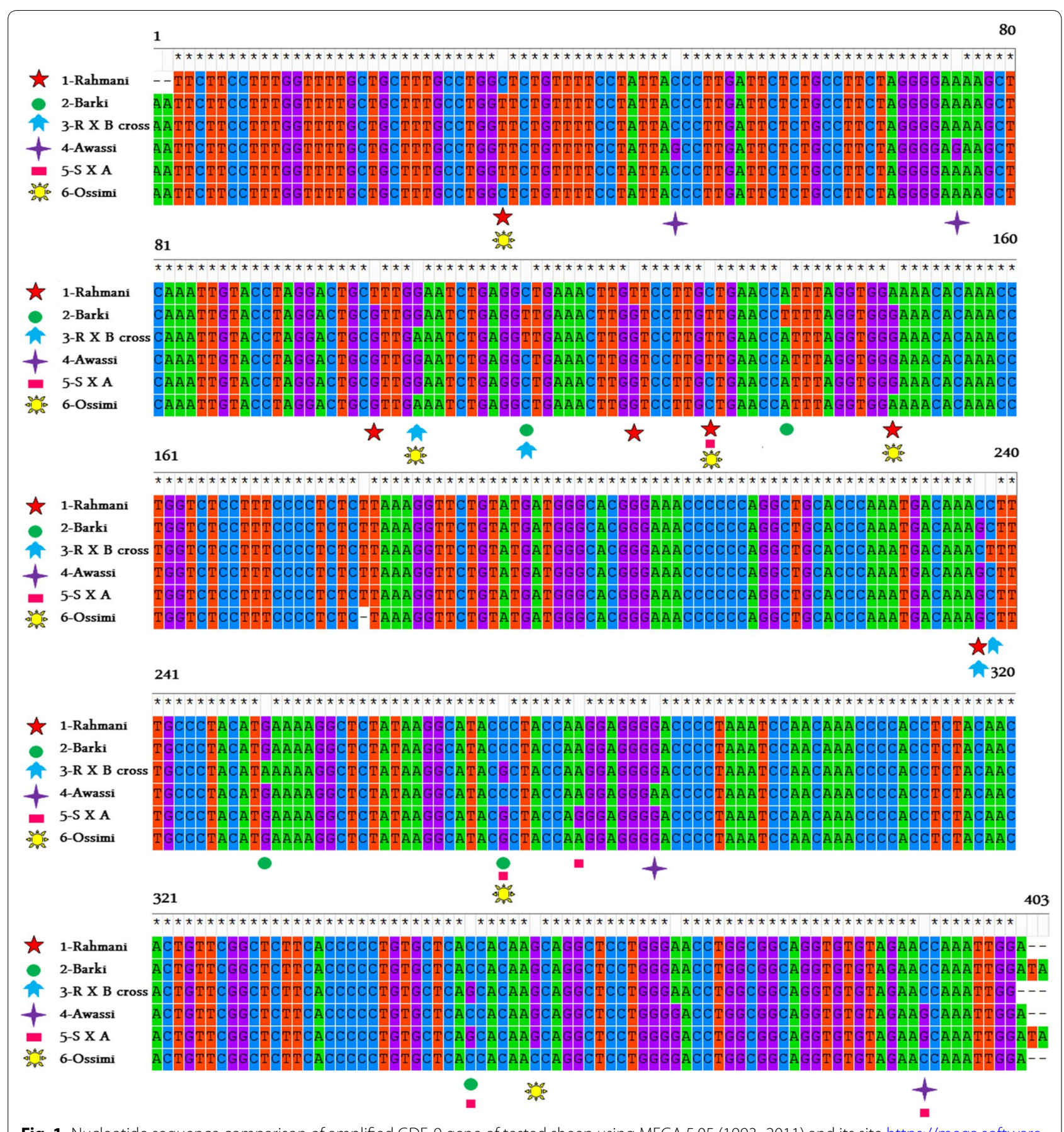

Fig. 1 Nucleotide sequence comparison of amplified GDF-9 gene of tested sheep using MEGA 5.05 (1993-2011) and its site https://mega.software. informer.com/5.0. RXB Rahmani X Barki cross and SXA Awassi X Suffolk cross

may form an advantage for the Egyptian sheep industry. Rahmani sheep are characterized by high prolificacy that could be associated with G allele of BMP-15 gene detected in that particular breed and its cross with Barki. Such high prolificacy could be due to the regulatory mechanism of the G allele of BMP-15 gene [5].
The relationship between fertility and the prevalence of BMP-15 (Fec $\left.-X^{G}\right)$ and GDF-9 (Fec- $\left.G^{H}\right)$ genotypes

Ovine BMP-15 gene plays a vital role in the growth and differentiation of early ovulation follicles and increased ovulation rate and LS under heterozygous conditions [25]. Interestingly, homozygous carriers for this mutation 


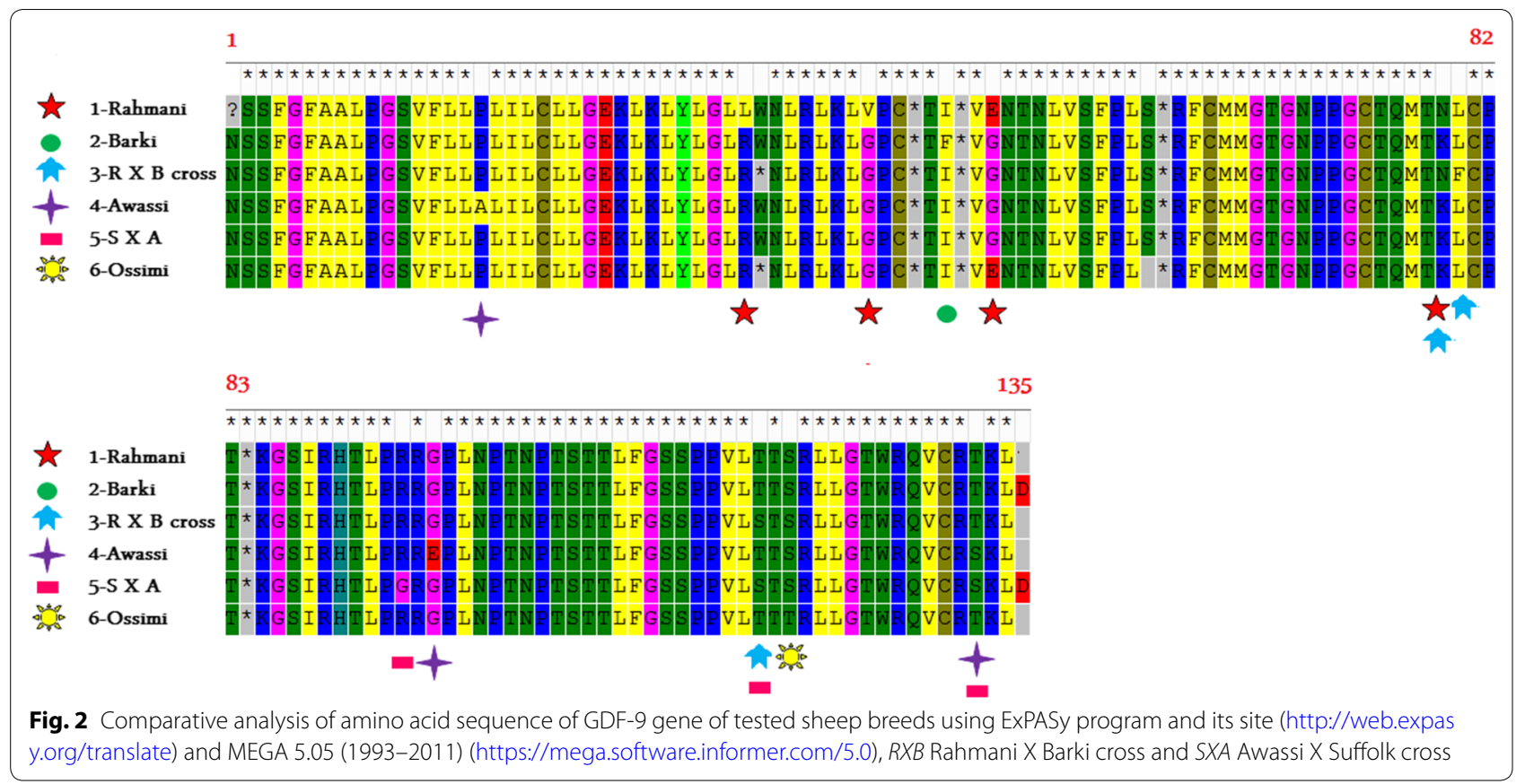

were infertile in some sheep breeds [7]. According to the results of nucleotide sequencing for GDF-9 gene and SSCP technique for BMP-15 gene, Rahmani breed and its cross with Barki carried the mutations Fec- $\mathrm{G}^{\mathrm{H}}$ of GDF-9 and Fec- $\mathrm{X}^{\mathrm{G}}$ of BMP-15 genes. Additionally, the replacement of amino acids for GDF9 may enhance the high rate of twinning $[18,26]$. This theory agrees with our results on the twinning rate in Rahmani and its cross with Barki compared to other breeds. High rate of twinning of 1.28 and 1.22 was recorded for Rahmani and its cross with Barki breeds, respectively. While the average of twinning rate for Barki, Ossimi, Awassi, and its cross with Suffolk had almost a constant values rate over six parities, ranging between 1.00 and 1.04 (Table 1).

\section{Limitations}

The prolificacy genotypes at genes BMPR-1B, GDF-9 and BMP-15 were found so far in the genomes of many prolific breeds throughout the world. More research on these genes in Egyptian sheep breeds is required for detection of more polymorphisms, comparisons of gene sequencing and tracing the evolutionary relatedness for gene sights among sheep breeds. More investigations to confirm and apply those advantages are necessary. Also, detection of useful genes or mutations as a primary step before transferring them to another breed, composite, or line either by crossing or even by more sophisticated techniques should help achieving the betters of their presence and avoid the damage that they may cause if compiled wrongly.

Table 1 Prolificacy means for some sheep breeds in different parities

\begin{tabular}{llllllll}
\hline Breeds & Parity & \multicolumn{1}{c}{} & \multicolumn{1}{c}{ Overall } \\
\cline { 2 - 6 } & $\mathbf{1}$ & $\mathbf{2}$ & $\mathbf{3}$ & $\mathbf{4}$ & $\mathbf{5}$ & $\mathbf{6}$ \\
\hline Rahmani & 1.17 & 1.00 & 1.33 & 1.50 & 1.17 & 1.50 & 1.17 \\
Barki & 1.00 & 1.00 & 1.00 & 1.00 & 1.00 & $1.28^{\mathrm{b}}$ \\
RXB & 1.00 & 1.22 & 1.47 & 1.13 & 1.33 & 1.17 & $1.03^{\mathrm{a}}$ \\
Awassi & 1.00 & 1.00 & 1.00 & 1.00 & 1.00 & 1.00 & $1.02^{\mathrm{b}}$ \\
SXA & 1.00 & 1.00 & 1.00 & 1.00 & 1.20 & 1.00 & $1.00^{\mathrm{a}}$ \\
Ossimi & 1.00 & 1.00 & 1.00 & 1.00 & & &
\end{tabular}

a, $b$ Means with different superscript letters in the same column are significantly different RXB Rahmani X Barki cross, SXA Awassi X Suffolk cross 


\section{Supplementary information}

Supplementary information accompanies this paper at https://doi. org/10.1186/s13104-020-05047-9.

Additional file 1: Fig.S1 (a): PCR amplification of BMPR-1B gene (190 bp), (b): BMP-15 gene (141 bp), and (c): GDF-9 gene (462 bp), for; Rahmani (R), Barki (B), Awassi (A), Rahmani X Barki cross (C), Awassi X Suffolk cross (S), and Ossimi (O). M, 50 bp/ 100 bp DNA ladder. Fig.S2 (a): The PCR products of the BMPR-1B (Fec-B) gene from the genomic DNA of tested breeds and digested by Avall. M; 50 bp DNA ladder, M*; 100 bp DNA ladder. (b): Digestion pattern of PCR amplification of the GDF-9 (Fec-GH) gene from the genomic DNA of tested breeds. (b1) and (b2) digestion profile with ASP-I and Hinf-I respectively, for; Rahmani (R), Barki (B), Awassi (A), Rahmani X Barki cross (C), Awassi X Suffolk cross (S), and Ossimi (O). M, 100 bp /50 bp DNA ladder, respectively. Fig.S3 (A) - A 462 bp sequence of GDF-9 gene of Rahmani breed (NCBI accession no. KT357481.1), (B) - A 462 bp sequence of GDF-9 gene of Barki breed (NCBl accession no. KT357482.1), (C) - A 462 bp sequence of GDF-9 gene of Rahmani X Barki cross breed (NCBl accession no. KT357484.1), (D) - A 462 bp sequence of GDF-9 gene of Awassi breed (NCBl accession no. KT357483.1), (E) - A 462 bp sequence of GDF-9 gene of Awassi X Suffolk cross breed (NCBl accession no. KT357485.1), (F) - A 462 bp sequence of GDF-9 gene of Ossimi breed (NCBI accession no. KT357486.1).

Additional file 2: Table S1 The listing primer and sequence $\left(5^{\prime} \rightarrow 3^{\prime}\right)$ of BMPR-1B, BMP-15, and GDF-9 genes. Table S2 Cycles conditions of PCR. Table S3 Nucleotide sequence distances: percent similarity (above diagonal), percent distance (below diagonal); of GDF-9 gene of tested sheep breeds. Table S4 The changed amino acids in tested sheep breeds. Table S5 Genotyping and allele frequencies analysis of the studied sheep breeds for BMPR-1B, and BMP-15 genes.

\section{Abbreviations}

BMPR-IB: Bone morphogenetic protein receptor-IB; GDF-9: Growth differentiation factor-9; BMP-15: Bone morphogenetic protein-15; PCR: Polymerase chain reaction; RFLP: Restriction fragment length polymorphism; SSCP: Single-strand conformational polymorphism.

\section{Acknowledgements}

The authors gratefully thank the working team of the Plant Protection and Biomolecular diagnosis Department_-Arid Lands Cultivation Research Institute (ALCRI) - The City of Scientific Research and Technology Applications, Also, the authors gratefully appreciate the efforts of the working team of Functional Foods \& Nutrition Laboratory (FFNL) -Dairy Science and Technology Department-Faculty of Agriculture (Alshatby) —Alexandria University, Alexandria, Egypt, which were really fruitful.

\section{Authors' contributions}

The work presented here was carried out in collaboration between all authors. $\mathrm{MSH}, \mathrm{AS}, \mathrm{ND}$, and $\mathrm{MH}$ defined the research theme. MSH, EH and AS designed methods and experiments, AS, EH and ND carried out the laboratory experiments, AS, and MSH organized the data, AS, MSH, and ND interpreted the results and wrote the manuscript. AS co-worked on associated data collection and their interpretation. All authors reviewed the manuscript. All authors read and approved the final manuscript.

\section{Funding}

Not applicable.

\section{Availability of data and materials}

All data generated or analyzed during this study are included in this manuscript and its Additional files: $(1,2)$.

\section{Ethics approval and consent to participate}

The consent to use the animals in the current study was obtained from the ethics committee of Animal and Fish Production Department, College of Agriculture, Alexandria University, Egypt (No. AFP7-AB1-2016). Also, all procedures and experimental protocols were in accordance with the Guide for the Care and Use of Agricultural Animals in Research and Teaching, Federation of Animal Science Societies (FASS, 2010) https://www.aaalac.org/about/ Ag_Guide_3rd_ed.pdf.

\section{Consent for publication}

Not applicable.

\section{Competing interests}

Dear Editor-in-Chief of BMC Research Notes Journal: The authors have no conflicts of interest to declare. This work is original and never published before. We have no conflict with any other scientist. [( declare that the authors have no competing interests as defined by BioMed Central, or other interests that might be perceived to influence the results and discussion reported in this paper)].

\section{Author details}

${ }^{1}$ College of Animal Science and Technology, Southwest University, Chongqing Key Laboratory of Forage \& Herbivore, Chongqing Engineering Research Center for Herbivores Resource Protection and Utilization, Beibei 400716, Chongqing, People's Republic of China. ${ }^{2}$ Animal and Fish Production Department, Faculty of Agriculture (Alshatby), Alexandria University, Alexandria, Egypt. ${ }^{3}$ Dairy Science and Technology Department, Faculty of Agriculture (Alshatby), Alexandria University, Alexandria, Egypt. ${ }^{4}$ Plant Protection and Bio-molecular diagnosis Department, Arid Lands Cultivation Research Institute (ALCRI), The City of Scientific Research and Technology Applications, Alexandria, Egypt.

Received: 4 February 2020 Accepted: 28 March 2020

Published online: 10 April 2020

\section{References}

1. Hayashi K. PCR-SSCP: a method for detection of mutations. Genet Anal. 1992;9(3):73-9.

2. Hafezian SH. Genetic polymorphism BMP15 and GDF9 genes in Sangsari sheep of Iran. Int J Genet Mol Biol. 2011;3(1):31-4.

3. Lan ZJ, Gu P, Xu X, Jackson KJ, DeMayo FJ, O'Malley BW, Cooney AJ. GCNFdependent repression of BMP-15 and GDF-9 mediates gamete regulation of female fertility. EMBO J. 2003;22(16):4070-81.

4. Adkinson AY, Adkinson RW. The FecB (Booroola) gene and implications for the Turkish sheep industry. Turkish J Vet Anim Sci. 2013;37(6):621-4.

5. Barakat IA, Salem LM, Daoud NM, Khalil WK, Mahrous KF. Genetic polymorphism of candidate genes for fecundity traits in Egyptian sheep breeds. Biomed Res. 2017;28(2):851-7.

6. Chu M, Liu Z, Jiao C, He Y, Fang L, Ye S, Chen G, Wang J. Mutations in BMPR-IB and BMP-15 genes are associated with litter size in small tailed han sheep (Ovis aries). J Anim Sci. 2007;85(3):598-603.

7. Chu M-X, Sang L-H, Wang J-Y, Fang L, Ye S-C. Study on BMP15 and GDF9 as candidate genes for prolificacy of small tail han sheep. Yi Chuan Xue Bao. 2005;32:38-45.

8. Kolosov AY, Getmantseva L, Shirockova N, Klimenko A, Bakoev SY, Usatov A, Bakoev N, Leonova M. Polymorphism of the GDF9 gene in Russian sheep breeds. J Cytol Histol. 2015;6(1):1.

9. Smith P, Hudson N, Shaw L, Heath D, Condell L, Phillips D, McNatty K. Effects of the Booroola gene (FecB) on body weight, ovarian development and hormone concentrations during fetal life. Reproduction. 1993:98(1):41-54

10. Smith P, Hudson N, Corrigan K, Shaw L, Smith T, Phillips D, McNatty K. Effects of the Booroola gene (FecBB) on bodymass, testis development and hormone concentrations during fetal life. J Reprod Fertil. 1996;108(2):253-61.

11. Shokrollahi B. Investigation of BMP15 gene polymorphisms associated with twining in Markhoz goat. Biharean Biologist. 2015;9(1):1-4.

12. Guo X, Wang X, Di R, Liu Q, Hu W, He X, Yu J, Zhang X, Zhang J, Broniowska K. Metabolic effects of FecB gene on follicular fluid and ovarian vein serum in sheep (Ovis aries). Int J Mol Sci. 2018;19(2):539.

13. Galloway SM, McNatty KP, Cambridge LM, Laitinen MP, Juengel JL, Jokiranta TS, McLaren RJ, Luiro K, Dodds KG, Montgomery GW. Mutations in an oocyte-derived growth factor gene (BMP15) cause increased ovulation rate and infertility in a dosage-sensitive manner. Nat Genet. 2000;25(3):279. 
14. Zhang C, Geng L, Liu Z, Fu Z, Feng M, Gong Y. Polymorphic study of FecXG, FecGH and FecB mutations in four domestic sheep breeds in the lower yellow river valley of China. J Anim Vet Adv. 2011;10(17):2198-201.

15. Vacca GM, Dhaouadi A, Rekik M, Carcangiu V, Pazzola M, Dettori ML. Prolificacy genotypes at BMPR 1B, BMP15 and GDF9 genes in North African sheep breeds. Small Ruminant Res. 2010;88(1):67-71.

16. Sambrook J, Fritsch E: Maniatis. 1989. Molecular cloning: a laboratory manual. In: Cold Spring Harbor Laboratory Press, Cold Spring Harbor, NY; 1997.

17. Wilson T, Wu X-Y, Juengel JL, Ross IK, Lumsden JM, Lord EA, Dodds KG, Walling GA, McEwan JC, O'Connell AR. Highly prolific Booroola sheep have a mutation in the intracellular kinase domain of bone morphogenetic protein IB receptor (ALK-6) that is expressed in both oocytes and granulosa cells. Biol Reprod. 2001;64(4):1225-35.

18. Hanrahan JP, Gregan SM, Mulsant P, Mullen M, Davis GH, Powell R, Galloway SM. Mutations in the genes for oocyte-derived growth factors GDF9 and BMP15 are associated with both increased ovulation rate and sterility in Cambridge and Belclare sheep (Ovis aries). Biol Reprod. 2004;70(4):900-9.

19. Bastos E, Cravador A, Azevedo J, Guedes-Pinto H. Single strand conformation polymorphism (SSCP) detection in six genes in Portuguese indigenous sheep breed'Churra da Terra Quente'. Biotechnologie, Agronomie, Société et Environ. 2001;5(1):7-15.

20. Abulyazid I, Abdalla M, Sharada H, Saleh H, Hassanin W. Prolificacy detection in Egyptian sheep using RFLP-specific PCR. Egypt Acad J Biological Sci. 2011;1:1-4.
21. El-Hanafy AA, El-Saadani M. Fingerprinting of FecB gene in five Egyptian sheep breeds. Biotechnol Anim Husbandry. 2009;25(3-4):205-12.

22. Guan F, Liu S-R, Shi G-Q, Yang L-G. Polymorphism of FecB gene in nine sheep breeds or strains and its effects on litter size, lamb growth and development. Anim Reprod Sci. 2007;99(1-2):44-52.

23. Noshahr FA, Rafat A. Genetic Polymorphism of GDF9 Gene in Iranian Moghani sheep breed. Iranian J Appl Anim Sci. 2014;4(4):887-90.

24. Ghaffari M, Nejati-Javaremi N, Rahimi-Mianji G. Lack of polymorphism in the oocyte derived growth factor (GDF9) gene in the Shal breed of sheep. S Af J Anim Sci. 2009. https://doi.org/10.4314/sajas.v39i4.51127.

25. Wan $Q$, Wang $Y$, Wang $H$. Identification and analysis of regulatory elements in porcine bone morphogenetic Protein 15 gene promoter. Int J Mol Sci. 2015;16(10):25759-72.

26. Marai IFM, Daader AH, Bahgat LB. Performance traits of purebred Ossimi and Rahmani lambs and their crosses with Finnsheep born under two accelerated mating systems. Arch Anim Breed. 2009;52(5):497-511.

\section{Publisher's Note}

Springer Nature remains neutral with regard to jurisdictional claims in published maps and institutional affiliations.
Ready to submit your research? Choose BMC and benefit from:

- fast, convenient online submission

- thorough peer review by experienced researchers in your field

- rapid publication on acceptance

- support for research data, including large and complex data types

- gold Open Access which fosters wider collaboration and increased citations

- maximum visibility for your research: over $100 \mathrm{M}$ website views per year

At BMC, research is always in progress.

Learn more biomedcentral.com/submissions 